\title{
Multiple aneurysms and Rosai-Dorfman disease: association or coincidence?
}

\author{
Yadala Ganesh, ${ }^{1}$ Vivek Yadala, ${ }^{2}$ Bhavana Vemula, ${ }^{2}$ Nalini Y Kammela ${ }^{3}$
}

${ }^{1}$ Department of General Medicine/Internal Medicine, Apollo Hospitals, Hyderabad, India

${ }^{2}$ Department of Internal Medicine, Apollo Hospital, Hyderabad, India

${ }^{3}$ Department of Radiation Oncology, Apollo Hospitals, Hyderabad, India

\section{Correspondence to} Dr Yadala Ganesh, yadalaganesh@yahoo.com

Accepted 3 September 2015
CrossMark

To cite: Ganesh $Y$ Yadala V, Vemula $B$, et al. BMJ Case Rep Published online: [please include Day Month Year] doi:10.1136/ bcr-2015-212189

\section{DESCRIPTION}

A 29-year-old man presented with a 1-month history of pain and numbness in his right arm and hypertension for 2 months, which was refractory to a combination of antihypertensive drugs. Physical examination revealed multiple pulsatile swellings in upper limbs and bilateral proptosis. No lymphadenopathy was noticed. The patient's blood pressure was $210 / 105 \mathrm{~mm} \mathrm{Hg}$. CT angiogram showed aneurysmal dilations in the left external carotid artery, left internal carotid artery, both axillary arteries and both renal arteries (figure 1). The right renal artery showed thrombosis (figure 2) and haemorrhage with non-functioning right kidney. Except for serum creatinine of $1.6 \mathrm{mg} \%$, laboratory reports, including antinuclear antibody profile, c-ANCA (antineutrophil cytoplasmic antibody), p-ANCA, whole body positron emission tomography (PET) CT scan and thyroid profile, were normal. The patient had

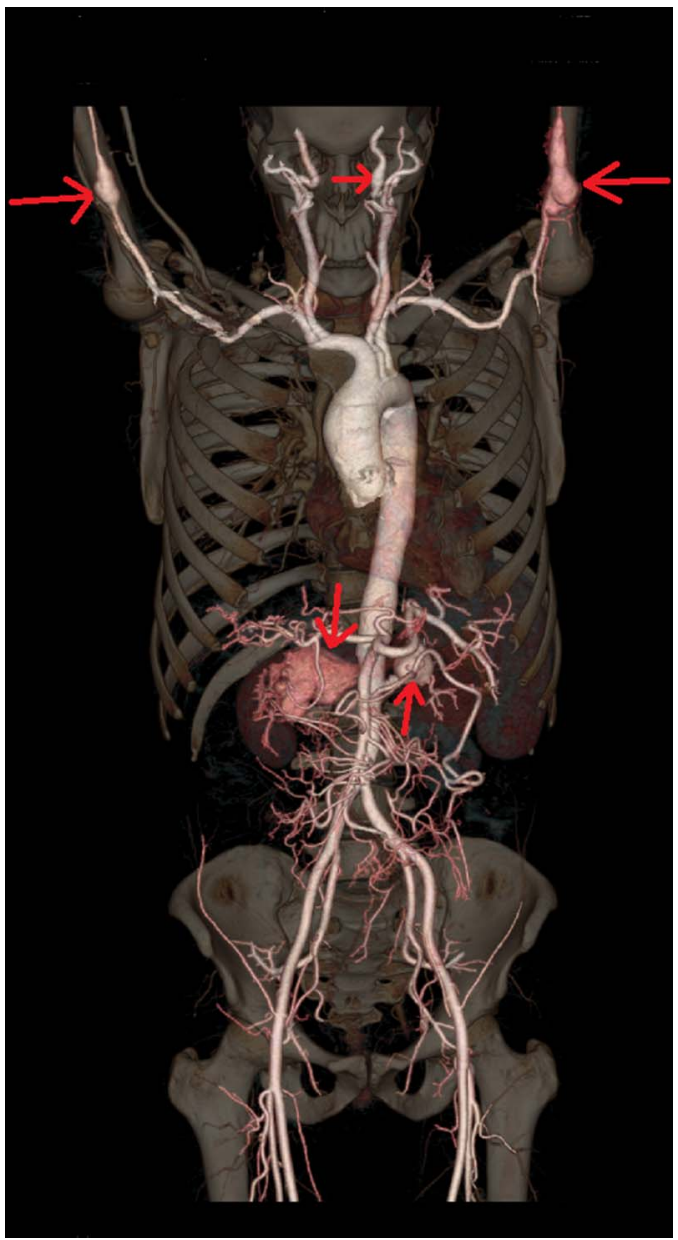

Figure $1 \mathrm{CT}$ angiogram showing aneurysmal dilations in left internal carotid artery, left external carotid artery, both axillary arteries and both renal arteries.

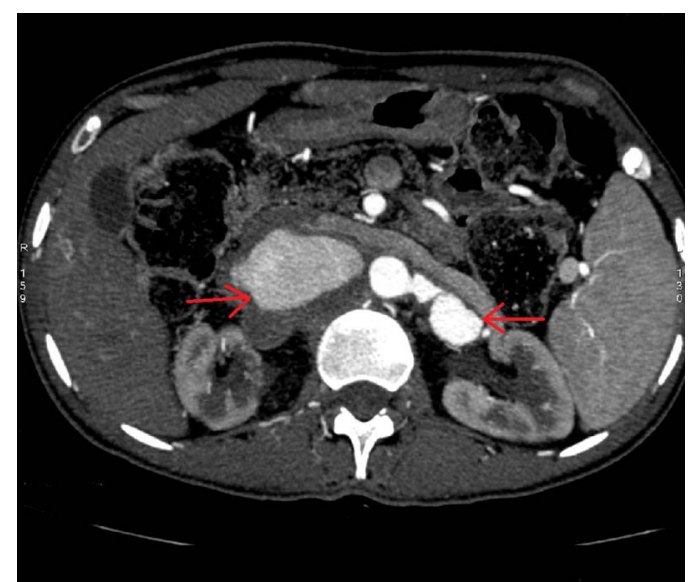

Figure 2 Right renal artery showing thrombosis and haemorrhage, and aneurysm in the left renal artery.

undergone surgical excision of a sinonasal mass 2 years earlier, the histopathological examination of which revealed Rosai-Dorfman disease (RDD).

RDD is a rare histiocytic disorder with excessive production of white cells called non-Langerhans sinus histiocytes. ${ }^{1}$ These cells accumulate in various areas of the body, leading to malfunction. They mainly deposit in lymph nodes, particularly in the cervical region. The condition was first described as a distinct pathological entity by Rosai and Dorfman in $1969 .^{2}$ Involvement of extra nodal sites including orbits with proptosis, salivary glands, testis and upper respiratory tract, has been reported. ${ }^{3}$ There have been reports of unconfirmed vasculitis in RDD and we are reporting a case of multiple aneurysms in a patient with RDD. A definite association between RDD and multiple aneurysms still needs to be established.

Acknowledgements The authors would like to acknowledge Dr Nori Vijaya Bhaskar, radiologist.

Contributors YG conceptualised the case and collected the data. VY reviewed the data and wrote the manuscript. NYK and BV reviewed and edited the manuscript.

Competing interests None declared.

Patient consent Obtained.

Provenance and peer review Not commissioned; externally pee reviewed.

\section{REFERENCES}

1 Weitzman S, Jaffe R. Uncommon histiocytic disorders: the non-Langerhans cell histiocytoses. Pediatr Blood Cancer 2005;45:256-64

2 Rosai J, Dorfman RF. Sinus histiocytosis with massive lymphadenopathy. A newly recognized benign clinicopathological entity. Arch Pathol 1969;87:63-70.

3 Tiju JW, Hsiao CH, Tsai TF. Cutaneous Rosai-Dorfman disease: remission with thalidomide treatment. $\mathrm{Br}$ I Dermatol 2003;148:1060-1. 
Copyright 2015 BMJ Publishing Group. All rights reserved. For permission to reuse any of this content visit http://group.bmj.com/group/rights-licensing/permissions.

BMJ Case Report Fellows may re-use this article for personal use and teaching without any further permission.

Become a Fellow of BMJ Case Reports today and you can:

- Submit as many cases as you like

- Enjoy fast sympathetic peer review and rapid publication of accepted articles

- Access all the published articles

- Re-use any of the published material for personal use and teaching without further permission

For information on Institutional Fellowships contact consortiasales@bmjgroup.com

Visit casereports.bmj.com for more articles like this and to become a Fellow 